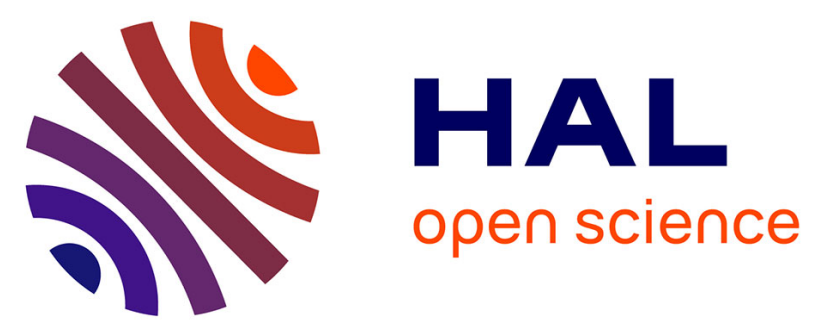

\title{
Do people living with HIV face more secondary cancers than general population: From the French CANCERVIH network
}

Marianne Veyri, Armelle Lavolé, Sylvain Choquet, Dominique Costagliola, Caroline Solas, Christine Katlama, Isabelle Poizot-Martin, Jean-Philippe Spano

\section{To cite this version:}

Marianne Veyri, Armelle Lavolé, Sylvain Choquet, Dominique Costagliola, Caroline Solas, et al.. Do people living with HIV face more secondary cancers than general population: From the French CANCERVIH network. Bulletin du Cancer, 2021, 155, 10.1016/j.bulcan.2021.01.026 . hal-03356180

\section{HAL Id: hal-03356180 \\ https://hal.sorbonne-universite.fr/hal-03356180}

Submitted on 27 Sep 2021

HAL is a multi-disciplinary open access archive for the deposit and dissemination of scientific research documents, whether they are published or not. The documents may come from teaching and research institutions in France or abroad, or from public or private research centers.
L'archive ouverte pluridisciplinaire HAL, est destinée au dépôt et à la diffusion de documents scientifiques de niveau recherche, publiés ou non, émanant des établissements d'enseignement et de recherche français ou étrangers, des laboratoires publics ou privés. 


\section{Do people living with HIV face more secondary cancers than general population: from the French CANCERVIH network}

\section{Les personnes vivant avec le VIH sont-elles plus confrontées à des seconds cancers que la population générale : travail issu du réseau CANCERVIH}

Marianne Veyri ${ }^{1}$, Armelle Lavolé2 ${ }^{2}$, Sylvain Choquet $^{3}$, Dominique Costagliola ${ }^{4}$, Caroline Solas ${ }^{5}$, Christine Katlama ${ }^{6}$, Isabelle Poizot-Martin ${ }^{7}$, Jean-Philippe Spano ${ }^{8}$

${ }^{1}$ AP-HP, Hôpitaux Universitaires Pitié-Salpêtrière - Charles Foix, Oncologie médicale, Sorbonne Université, INSERM, Institut Pierre Louis d'Epidémiologie et de Santé Publique, équipe Theravir, 4783 boulevard de l'Hôpital 75013 Paris, France

2Sorbonne Université, GRC n4, Theranoscan, AP-HP, Service de Pneumologie, Hôpital Tenon, 4 rue de la Chine 75020 Paris, France

${ }^{3}$ AP-HP, Hôpitaux Universitaires Pitié-Salpêtrière - Charles Foix, Hématologie Clinique, 47-83 boulevard de l'Hôpital 75013 Paris, France

4Sorbonne Université, INSERM, IPLESP (Institut Pierre Louis d'Epidémiologie et de Santé Publique), 47-83 boulevard de l'Hôpital 75013 Paris, France

${ }^{5}$ Aix Marseille Univ, APHM, INSERM 1207, IRD 190, UVE, Hôpital La Timone, Laboratoire de Pharmacocinétique et Toxicologie, 264 rue Saint-Pierre 13005 Marseille, France

${ }^{6}$ Sorbonne Université, INSERM, Institut Pierre Louis d'Epidémiologie et de Santé Publique, équipe Theravir, AP-HP, Hôpitaux Universitaires Pitié Salpêtrière - Charles Foix, Maladies Infectieuses et Tropicales, 47-83 boulevard de l'Hôpital 75013 Paris, France

${ }^{7}$ Aix Marseille Univ, APHM, INSERM, IRD, SESSTIM, Sciences Economiques \& Sociales de la Santé \& Traitement de l'Information Médicale, Hôpital Sainte-Marguerite, Service d'Immuno-hématologie clinique, 270 boulevard de Sainte-Marguerite 13009 Marseille, France 8Sorbonne Université, INSERM, Institut Pierre Louis d'Epidémiologie et de Santé Publique, équipe Theravir, AP-HP, Hôpitaux Universitaires Pitié-Salpêtrière - Charles Foix, Oncologie médicale, 47-83 boulevard de l'Hôpital 75013 Paris, France 
Corresponding author: Marianne Veyri, Medical Oncology department, Pitié-Salpêtrière Hospital, 4783 boulevard de l'Hôpital, 75013 Paris, +33 (0)1 42160026 marianne.veyri@aphp.fr 


\section{ABSTRACT}

Introduction: People living with HIV (PLWHIV) are at a higher risk of cancer compared to the general population. With improved cancer treatments and the increased life expectancy of PLWHIV, the incidence of second cancers is also expected to increase.

Methods: We reviewed the cases of PLWHIV with cancer that have been presented to the CANCERVIH national multidisciplinary board since 2014. We included all cases with a history of cancer, and studied the incidence and types of second cancers.

Results: 719 cases were reviewed, out of which 94 (13\%) had a history of at least one cancer. For the first primary cancers, 46 (49\%) were AIDS-defining cancers (ADCs) and 48 (51\%) were non-AIDS-defining cancers (NADCs). Kaposi sarcoma (33\%) and NHL (15\%) occurred most frequently as first cancers.

Among the first cancers that were ADCs, $15 \%$ of the second cancers were $\mathrm{NHL}, 11 \%$ anal canal cancers, $9 \%$ bladder and $9 \%$ Hodgkin lymphomas. Among the first cancers that were NADCs, $38 \%$ of the second cancers were lung cancers, $8 \%$ bladder, $8 \%$ head and neck and $8 \% \mathrm{NHL}$.

Discussion: With the aging of PLWHIV, the incidence of second and subsequent cancers is expected to increase in this population. Immuno-virological control should be maintained. Increased surveillance, early prevention and screening programs should be offered to all PLWHIV, including those with an undetectable HIV viral load and/or immune restoration. 


\section{RESUME}

Introduction : Les personnes vivant avec le VIH (PVVIH) ont un risque plus élevé de cancer que la population générale. Avec l'amélioration des traitements carcinologiques et l'augmentation de l'espérance de vie des PVVIH, l'incidence des seconds cancers devrait augmenter.

Méthodes : Nous avons examiné les dossiers des PVVIH atteintes d'un cancer qui ont été présentés en RCP nationale CANCERVIH depuis 2014. Nous avons inclus tous les cas avec antécédents de cancer, et étudié l'incidence et les types de seconds cancers.

Résultats : 719 dossiers ont été examinés dont 94 (13\%) avaient un antécédent d'au moins un cancer. Pour les premiers cancers primitifs, 46 (49\%) étaient des cancers classant-SIDA (ADCs) et 48 (51\%) des cancers non-classant-SIDA (NADCs). Le sarcome de Kaposi (33 $\%)$ et le LNH (15\%) étaient les premiers cancers les plus fréquents.

Parmi les premiers cancers qui étaient des ADCs, $15 \%$ des seconds cancers étaient des $\mathrm{LNH}, 11 \%$ des cancers du canal anal, $9 \%$ de vessie et $9 \%$ des lymphomes de Hodgkin. Parmi les premiers cancers qui étaient des NADCs, $38 \%$ des seconds cancers étaient des cancers du poumon, $8 \%$ de vessie, $8 \%$ de la tête et cou et $8 \%$ des $\mathrm{LNH}$.

Discussion : Avec le vieillissement des PVVIH, l'incidence des seconds cancers (et ultérieurs) devrait augmenter dans cette population. Le contrôle immuno-virologique doit être maintenu. Surveillance accrue, prévention précoce et programmes de dépistage devraient être proposés à toutes les PVVIH, même avec une charge virale VIH indétectable et/ou une restauration immunitaire.

Keywords: AIDS-defining cancers, non-AIDS-defining cancers, HIV, second cancer Mots clés : cancers classant-SIDA, cancers non-classant-SIDA, VIH, second cancer This study was the subject of a poster at ESMO 2019 (\# 2036P). 


\section{INTRODUCTION}

The life expectancy of people living with HIV (PLWHIV) has considerably improved since the advent of effective antiretroviral therapy (ART) in 1996, approaching that of the general population $^{1 ; 2}$. As a consequence, causes of mortality in PLWHIV have shifted from AIDS to non-AIDS causes, making non-AIDS-related cancers the leading cause of non-AIDS deaths in PLWHIV1;3;4;5. PLWHIV are at increased risk of cancer compared to the general population, as a result of chronic immunosuppression, concomitant infection with oncogenic viruses (human papillomavirus [HPV], hepatitis B [HBV] and C [HCV] viruses, Epstein-Barr Virus [EBV]), as well as prevalence of smoking and alcohol use in the HIV-positive population 6;7;89. Cancers in PLWHIV are typically divided into AIDS-defining cancers, which are known to occur at increased rates and mark the onset of AIDS (ADCs: Kaposi sarcoma, non-Hodgkin lymphoma [NHL] and cervical cancer) and non-AIDS-defining cancers (NADCs). The incidence of ADCs has declined since the introduction of ART, but the risk of NADCs has increased with the growth and aging of the HIV-positive population $4 ; 8 ; 10$.

Due to improved outcomes of cancer patients, the population of cancer survivors is growing, with a 5-year cancer prevalence of 1.39 million in France alone (Globocan 2018). Studies on the incidence of second cancers have shown that cancer survivors are at an increased risk of developing a new cancer compared to the general population, due in part to late effects of cancer treatments, but also etiologic and environmental factors ${ }^{11 ; 12}$. Due to the longer survival of PLWHIV, the incidence of secondary cancers is also expected to increase in PLWHIV. Furthermore, PLWHIV have been shown to have worse survival from cancer compared to non-infected individuals ${ }^{13 ; 14}$. Improvements in cancer prevention, screening and treatment are therefore crucial in high-risk populations such as PLWHIV who have had cancer. However, data is limited on the risk of second cancer in PLWHIV. In a study that assessed the incidence of second cancers in PLWHIV using the San Francisco HIV/AIDS case registry and California Cancer Registry, PLWHIV were shown to have an increased risk for both first and second primary cancers, before and in the era of effective ART, in particular Kaposi sarcoma, NHL, Hodgkin's lymphoma, anal cancer, and liver cancer ${ }^{15}$. This study also 
showed that while first and second primary ADC incidence declined, second primary NADC incidence increased over time. Many of the cancers in excess had viral causes, or were related to smoking or alcohol use.

We conducted a study of a national prospective database of PLWHIV with cancer to evaluate the incidence of secondary cancer in PLWHIV, analyze the types of cancer and sequence of occurrence.

\section{METHODS}

\section{Study design and data collection}

This was an observational study to evaluate the incidence of secondary cancers in PLWHIV in the CancerVIH database. CancerVIH is a national multidisciplinary network dedicated to HIV-infected patients with cancer ${ }^{16}$ accredited by the French National Cancer Institute, and that has obtained all the necessary regulatory approvals (French IRB [n¹5-009], CCTIRS [n`16-391] and the Commission Nationale de l'Informatique et les Libertés [CNIL; n॰916500]). CancerVIH established a database in May 2014 to prospectively include new cases of PLWHIV with cancer. Each case is discussed during the bi-monthly national multidisciplinary board, composed of oncologists, radiotherapists, hematologists, infectiologists, virologists, immunologists and pharmacologists, in web-conference. Anonymized medical files are presented by the patients' referring physicians (HIV specialist or oncologist). Cases are presented on a regular basis by 109 centres in France (and a few centres in Switzerland which do not have a similar referral network).

We reviewed all cases in the CancerVIH database between 6 May 2014 (database creation date) and 31 December 2019.

For this study, we examined the history of cancer indicated by the referring physicians. History of cancer that was neither metastasis nor locoregional relapse was considered as primary cancer. We included in the analysis patients with prior cancer at a different site, at the same site with a different histology or a concomitant cancer at a different site or with a different histology. 
Patients with more than one previous malignant disease were included.

Demographic, epidemiological and immuno-virological characteristics were described at the time of the last cancer diagnosis.

\section{RESULTS}

\section{Patient characteristics}

In total, 719 cancer cases were reviewed. All patients were aged 18 or older and $97 \%$ were on ART. Among all these cases, 94 patients (13\%) had a history of at least one previous cancer. Patient characteristics are summarized in Table 1.

Of those 94 patients, 80 (84\%) were men and 14 (16\%) were women. All were under ART. The median age at onset of first cancer was 51 years for all patients (51 years for men, 48 years for women). The median age at onset of second cancer was 56 years for all patients (58 years for men, 52,5 years for women). The median CD4 nadir was $80 \mathrm{cells} / \mathrm{mm}^{3}$. At the time of diagnosis of the last cancer, the median time spent on ART was 15 years. The median CD4 count was 400 cells $/ \mathrm{mm}^{3}$ and all patients were with undetectable HIV viral load. Among the 22 patients (23\%) who had more than 2 cancers: 16 patients (17\%) had 3 cancers, 3 patients (5\%) had 4 cancers, 2 patients (2\%) had 5 cancers and 1 patient (1\%) had 7 cancers. The median time from first cancer to second cancer was 8,5 years.

\section{Cancer types and sequence of occurrence}

For the first primary cancers, 46 were ADCs (49\%) and $48(51 \%)$ were NADCs (Figure 1). Kaposi sarcoma (33\%) and non-Hodgkin lymphoma (15\%) occurred most frequently as first cancers. The most frequent first primary non-AIDS-defining cancers were head and neck (7\%), breast (5\%), Hodgkin lymphoma (5\%), and prostate cancers $(5 \%)$. Among the first cancers that were AIDS-defining cancers, $15 \%$ of the second cancers were NHL, $11 \%$ anal canal cancers, $9 \%$ bladder cancers and 9\% Hodgkin lymphomas. Among the first cancers that were non-AIDS-defining cancers, $38 \%$ of the second cancers were lung cancers, $8 \%$ bladder, $8 \%$ head and neck and $8 \% \mathrm{NHL}$. 


\section{DISCUSSION}

In this study, we evaluated the incidence of second cancers in a population of PLWHIV with cancer in a national database. Overall, $13 \%$ of patients had second or subsequent cancers, a higher proportion than that found in the study on HIV-positive San Francisco residents diagnosed with cancer between 1985 and $2013(9 \%, 372 / 4144)^{15}$. It was also higher than the incidence of second cancer $(7.3 \%)$ in the general population found in a study using data from the French network of cancer registries (FRANCIM) of nearly 290,000 patients diagnosed with cancer between 1989 and $2004^{17}$ and that in another study using surveillance data of over 2 million patients in the U.S. diagnosed with one of the ten most common cancers between 1992 and $2008(8 \%)^{18}$. Nevertheless, the proportion was getting closer to that of second cancers in the general population of cancer survivors in the U.S. according to Surveillance, Epidemiology, and End Results $\left(14-18 \%{ }^{11 ; 12 ; 19}\right)$.

The types of first cancer in this study were almost equally divided into ADCs and NADCs (49\% and 51\%, respectively). Kaposi sarcoma and NHL occurred most frequently as first cancer (33\% and 15\%, respectively). For those who had Kaposi sarcoma, the most common secondary cancers were $\mathrm{NHL}(19 \%)$ and anal canal cancer (13\%). In the San Francisco registry study, $50 \%$ of the HIV-positive patients diagnosed with cancer between 1990 and 2010 had a Kaposi sarcoma and 20\% NHL as first cancer ${ }^{11}$.

The most frequent first primary NADCs were head and neck cancers $(7 \%)$, breast $(5 \%)$, prostate $(5 \%)$, Hodgkin lymphoma $(5 \%)$, kidney (4\%), anal canal $(3 \%)$ and melanoma (3\%). Many of the NADCs either as first or subsequent cancer we observed in this study could be due, at least in part, to viral causes, notably ano-genital and oropharyngeal cancers (HPV) and Hodgkin lymphoma (EBV). Lifestyle factors, such as smoking and alcohol use, may also put PLWHIV at risk of second cancers. Among the most common NADCs that could be related to smoking and alcohol use were lung, head and neck, liver and pancreas. However, factors other than smoking may explain the high incidence of lung cancer in the HIV-positive population ${ }^{20-21}$. Biomarkers need to be identified for efficient prevention of the most common second cancers such as anal cancer ${ }^{22}$, and interventions should be pursued 
to encourage modification of cancer-associated lifestyles (smoking and alcohol consumption).

Immunosuppression caused by HIV infection and implicated in the development of certain cancers is increased by low CD4 nadir and prolonged duress without effective ARV treatment. ARV treatment should be started as early as possible and continued for life, even during cancer treatment, in order to maintain high CD4 counts and an undetectable viral load.

Our study has several limitations. This was a retrospective observational study with a relatively small sample size. Data on lifestyle habits (tobacco and/or alcohol consumption) and all previous treatments are not systematically collected and could not be studied. Nevertheless, patients were included in the database prospectively, and the database is not exhaustive knowing the fact that the incidence in France of cancer in PLWHIV is about $13 \%{ }^{1}$. Referring physicians call indeed on the network for the most serious cases requiring an appeal decision. In addition, our study population was predominantly male (84\%), thereby further limiting the sample size of female PLWHIV and their malignancies.

With the aging of PLWHIV, the incidence of second and subsequent cancers is expected to increase in this population, who are at risk for both ADCs and NADCs. Our findings strongly suggest the importance of effective screening and prevention of all types of cancers in PLWHIV. Immuno-virological control should be maintained in PLWHIV with cancer. Increased surveillance, early prevention including vaccination and screening programs should be offered to PLWHIV with previous cancer history, including those with an undetectable HIV viral load and/or immune restoration. 
Table 1: Patient characteristics

\begin{tabular}{|c|c|}
\hline Patient characteristics & Number of patients \\
\hline \multicolumn{2}{|l|}{ Sex } \\
\hline Male & $80(84 \%)$ \\
\hline Female & $14(16 \%)$ \\
\hline $\begin{array}{l}\text { Median age } 1^{\text {st }} \text { cancer (all genders) } \\
\text { Male } \\
\text { Female }\end{array}$ & $\begin{array}{l}50 \text { years (IQR, } 41,5-56) \\
51 \text { years (IQR, 42-59) } \\
48 \text { years (IQR, 36,5-54) }\end{array}$ \\
\hline $\begin{array}{l}\text { Median age } 2^{\text {nd }} \text { cancer (all genders) } \\
\text { Male } \\
\text { Female }\end{array}$ & $\begin{array}{l}56 \text { years (IQR, } 51-64) \\
58 \text { years (IQR, } 51-64) \\
52,5 \text { years (IQR, 46-64) } \\
\end{array}$ \\
\hline Median CD4 nadir & 80 cells/mm³ (IQR, 17-156,5) \\
\hline Time exposure to ART & 15 years $(\mathrm{IQR}, 9-23)$ \\
\hline Median CD4 & 400 cells $/ \mathrm{mm}^{3}$ (IQR, 222,5-651) \\
\hline Median HIV VL & $0 \mathrm{cp} / \mathrm{mL}(\mathrm{IQR}, 0-0)$ \\
\hline \multicolumn{2}{|l|}{ Year of discovery of HIV infection } \\
\hline Before 1997 & $47(50 \%)$ \\
\hline $1997-2000$ & $19(20 \%)$ \\
\hline 2001-2004 & $3(3 \%)$ \\
\hline 2005-2009 & $12(13 \%)$ \\
\hline After 2009 & $12(13 \%)$ \\
\hline Undetermined & $1(1 \%)$ \\
\hline \multicolumn{2}{|l|}{$\begin{array}{l}\text { Delay between HIV diagnosis } \\
\text { and cancer diagnosis }\end{array}$} \\
\hline $\begin{array}{l}\text { History of first cancer prior to HIV } \\
\text { diagnosis }\end{array}$ & $4(4 \%)$ \\
\hline $\begin{array}{l}\text { Concomitant diagnosis of HIV } \\
\text { and first cancer }\end{array}$ & $10(11 \%)$ \\
\hline 1 year after HIV diagnosis & $6(6 \%)$ \\
\hline Between 2 and 5 years after & $7(7 \%)$ \\
\hline Between 6 and 10 years after & $10(11 \%)$ \\
\hline Between 11 and 20 years after & $23(24 \%)$ \\
\hline More than 21 years later & $11(12 \%)$ \\
\hline Data not filled in & $23(24 \%)$ \\
\hline \multicolumn{2}{|l|}{ First primary cancers } \\
\hline ADC & $46(49 \%)$ \\
\hline NADC & $48(51 \%)$ \\
\hline \multicolumn{2}{|l|}{$\begin{array}{l}\text { Second cancer with an ADC first } \\
\text { primary cancer }\end{array}$} \\
\hline $\mathrm{NHL}$ & $7(15 \%)$ \\
\hline Bladder cancer & $5(11 \%)$ \\
\hline Canal anal cancer & $5(11 \%)$ \\
\hline Hodgkin lymphoma & $4(9 \%)$ \\
\hline Head and neck cancer & $3(7 \%)$ \\
\hline Lung cancer & $3(7 \%)$ \\
\hline Castleman disease & $3(7 \%)$ \\
\hline Liver cancer & $2(4 \%)$ \\
\hline Colorectal cancer & $2(4 \%)$ \\
\hline
\end{tabular}




\begin{tabular}{|l|l|} 
Biliary cancer & $2(4 \%)$ \\
Other & $10(20 \%)$ \\
\hline $\begin{array}{l}\text { Second cancer with a NADC first } \\
\text { primary cancer }\end{array}$ & \\
Lung cancer & $18(38 \%)$ \\
Bladder cancer & $4(8 \%)$ \\
Head and neck cancer & $4(8 \%)$ \\
NHL & $4(8 \%)$ \\
Kidney cancer & $2(4 \%)$ \\
Colorectal cancer & $2(4 \%)$ \\
Breast cancer & $2(4 \%)$ \\
Other & $12(25 \%)$ \\
\hline Median time from 1st cancer to 2 & 8,5 years (IQR, 3-12) \\
cancer &
\end{tabular}


Figure 1: description of the second cancers in relation to the first cancer

$14 \mathrm{NHL}$
(2) Livercancer
(2) Peniscancer
(2) NHL - (3) Colorectal cancer
(2) Prostate cancer - (3) NHL
(2) Kidney cancer - (3) Hodgkin lymphoma
(2) Vulva cancer - (3) Lung cancer
(2) Melanoma - (3) Anal canal cancer - (4) Head and Neck cancer

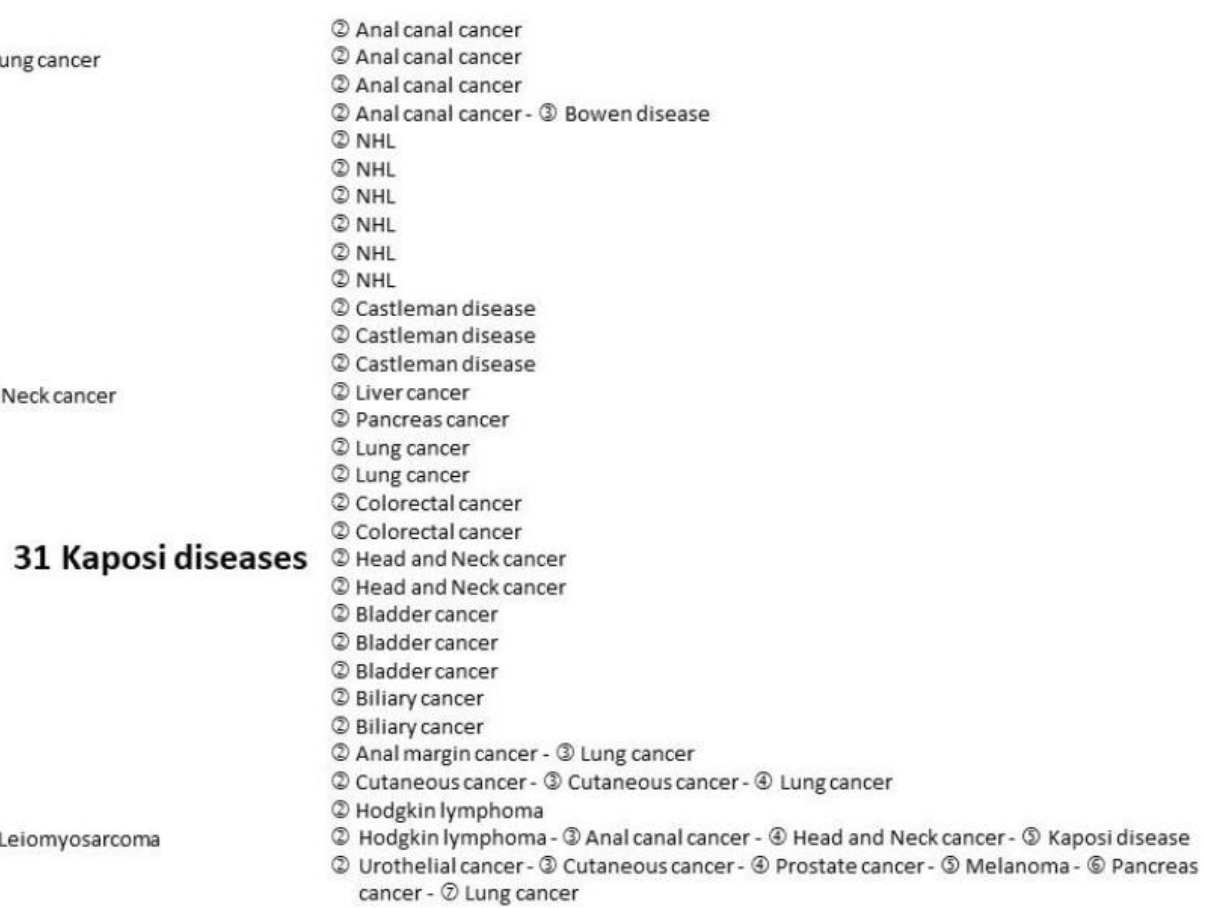

ADC (AIDS-defining cancer) as first cancer

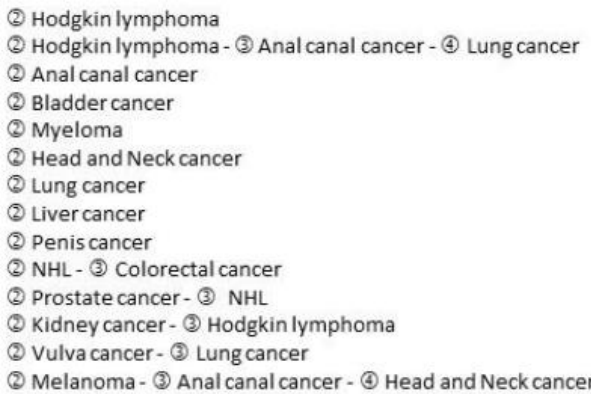

Anal canal cancer - (3) Bowen disease

(2) $\mathrm{NHL}$

$\mathrm{NHL}$

Castleman diseas

(2) Colorectal cancer

Anal margin cancer - (3) Lung cancer

(2) Hodgkin lymphoma

1 cervix cancer (2) Leiomyosarcoma cancer - () Lung cancer

7 Head and Neck cancers (2) Lung cancer (2) Bladdercancer

(2) Head and Neck cancer - (3) Lung cancer

(2) Head and Neckcancer - (3) Head and Neck cancer - (4) Head and Neckcancer - (5) Head and Neck cancer
(2) Head and Neck cancer (2) NHL

5 Breast cancers (2) Lung cancer (2) Lung cancer (2) Lung cancer
(2) NHL

5 Hodgkin lymphomas (2) Lung cancer

(2) Lung cancer

(2) Lung cancer

(2) Hodgkin lymphoma - (3) MDS

\section{Melanomas \\ (2) Melanoma - (3) Bladder cancer \\ (2) Breast cancer}

(2) Bladder cancer

\section{Anal margin cancers (2) Bowendisease}

1 Colorectal cancer (2) Kidneycancer-(3) Colorectal cancer

\section{Cutaneous cancers (2) Rectal cancer \\ (2) Kaposidisease-(3) Head and Neck cancer 1 Gastric cancer (2) Bladder cancer-(3) Kaposi disease}

2 Eye cancers (2) MLningioma - (3) Head and Neck cancer

NADC (Non-AIDS-defining cancer) as first cancer
1 Thyroid cancer (2) Head and Neck cancer

1 Ovarian cancer (2) Lung cancer

1 Vulvar cancer (2) Anal canal cancer 


\section{ACKNOWLEDGEMENTS}

We would like to thank the entire scientific council of the CANCERVIH network as well as all the referring physicians of the patients and the French Cancer Institute (INCa).

\section{COMPLIANCE WITH ETHICAL STANDARDS}

Role of the funding source: This study was funded by the French Cancer Institute (INCa) as part of the annual funding of the CANCERVIH network.

Conflict of Interest: Veyri M, Lavolé A, Choquet S, Costagliola D, Solas C, Katlama C and Poizot-Marin I declare that they have no conflict of interest.

Spano JP has no direct conflict of interest but received an honorarium as a consultant for Roche, MSD and Biogaran and has received a speaker honorarium from MSD, Roche, AstraZeneca, Leopharma, Mylan, Pfizer, BMS, Novartis, PFO, Myriads, Gilead and Lilly.

Ethical approval: This article does not contain any studies with human participants performed by any of the authors. This is a non-interventional study.

\section{REFERENCES}

1. Smith CJ, Ryom L, Weber R, Morlat P, Pradier C, Reiss P, et al. Trends in underlying causes of death in people with HIV from 1999 to 2011 (D:A:D): a multicohort collaboration. Lancet. 2014;384(9939):241-8.

2. Antiretroviral Therapy Cohort Collaboration. Survival of HIV-positive patients starting antiretroviral therapy between 1996 and 2013: a collaborative analysis of cohort studies. Lancet HIV. 2017;4(8):e349-e56. 
3. Antiretroviral Therapy Cohort Collaboration. Causes of death in HIV-1-infected patients treated with antiretroviral therapy, 1996-2006: collaborative analysis of 13 HIV cohort studies. Clin Infect Dis. 2010;50(10):1387-96.

4. Simard EP, Pfeiffer RM, Engels EA. Mortality due to cancer among people with AIDS: a novel approach using registry-linkage data and population attributable risk methods. AIDS. 2012;26(10):1311-8.

5. Weber R, Ruppik M, Rickenbach M, Spoerri A, Furrer H, Battegay M, et al. Decreasing mortality and changing patterns of causes of death in the Swiss HIV Cohort Study. HIV Med. 2013;14(4):195-207.

6. Grulich AE, van Leeuwen MT, Falster MO, Vajdic CM. Incidence of cancers in people with HIV/AIDS compared with immunosuppressed transplant recipients: a meta-analysis. Lancet. 2007;370(9581):59-67.

7. Engels EA, Biggar RJ, Hall HI, Cross H, Crutchfield A, Finch JL, et al. Cancer risk in people infected with human immunodeficiency virus in the United States. Int J Cancer. 2008;123(1):187-94.

8. Shiels MS, Pfeiffer RM, Gail MH, Hall HI, Li J, Chaturvedi AK, et al. Cancer burden in the HIV-infected population in the United States. J Natl Cancer Inst. 2011;103(9):753-62.

9. Hernández-Ramírez RU, Shiels MS, Dubrow R, Engels EA. Cancer risk in HIV-infected people in the USA from 1996 to 2012: a population-based, registry-linkage study. Lancet HIV. 2017;4(11):e495-e504.

10. Engels EA, Yanik EL, Wheeler W, Gill MJ, Shiels MS, Dubrow R, et al. CancerAttributable Mortality Among People With Treated Human Immunodeficiency Virus Infection in North America. Clin Infect Dis. 2017;65(4):636-43. 
11. Curtis RE, Freedman DM, Ron E, Ries LAG, Hacker DG, Edwards BK, et al. (eds). New malignancies among cancer survivors: SEER Cancer Registries, 1973-2000. National Cancer Institutue, NIH Publ. No. 05-5302. Bethesda, MD, 2006.

12. Travis LB, Demark Wahnefried W, Allan JM, Wood ME, Ng AK. Aetiology, genetics and prevention of secondary neoplasms in adult cancer survivors. Nat Rev Clin Oncol. 2013;10(5):289-301.

13. Coghill AE, Shiels MS, Suneja G, Engels EA. Elevated Cancer-Specific Mortality Among HIV-Infected Patients in the United States. J Clin Oncol. 2015;33(21):2376-83.

14. Marcus JL, Chao C, Leyden WA, Xu L, Yu J, Horberg MA, et al. Survival among HIVinfected and HIV-uninfected individuals with common non-AIDS-defining cancers. Cancer Epidemiol Biomarkers Prev. 2015;24(8):1167-73.

15. Hessol NA, Whittemore H, Vittinghoff E, Hsu LC, Ma D, Scheer S, et al. Incidence of first and second primary cancers diagnosed among people with HIV, 1985-2013: a populationbased, registry linkage study. Lancet HIV. 2018;5(11):e647-e55.

16. Gobert A, Spano JP, Cadranel J. HIV-associated cancers: the role of a unique multidisciplinary board to optimize patient's care behalf the CANCERVIH Group. Med Oncol. 2018;36(1):13.

17. Jégu J, Mutzig N, Velten M, et al. Estimation du risque de second cancer en France/ Etude à partir des registres des cancers du réseau Francim, les données, avril 2015. INCA, Boulogne-Billancourt, 2015.

18. Donin N, Filson C, Drakaki A, Tan HJ, Castillo A, Kwan L, et al. Risk of second primary malignancies among cancer survivors in the United States, 1992 through 2008. Cancer. 2016;122(19):3075-86. 
19. Murphy CC, Gerber DE, Pruitt SL. Prevalence of Prior Cancer Among Persons Newly Diagnosed With Cancer: An Initial Report From the Surveillance, Epidemiology, and End Results Program. JAMA Oncol. 2018;4(6):832-6.

20. Sigel H, Wisnivesky J, Gordon K, Dubrow R, Justice A, Brown ST, Goulet J, Butt AA, Crystal S, Rimland D, Rodriguez-Barradas M, Gibert C, Parl LS, Crothers K. HIV as an independent risk factor for incident lung cancer. AIDS. 2012:26(8):1017-25.

21. Helleberg M, Gerstoft J, Afzal S, Kronborg G, Larsen CS, Pedersen C, Bojesen SE, Nordestgaard BG, Obel N. Risk of cancer among HIV-infected individuals compared to the background population: impact of smoking and HIV. AIDS 2014:1499-508.

22. Schim van der Loeff MF. Secondary anal cancer prevention in the HIV-infected: a step ahead but a long way to go. AIDS. 2018;32(16):2425-7. 